\title{
Extracted tetrodotoxin from puffer fish Lagocephalus lagocephalus induced hepatotoxicity and nephrotoxicity to Wistar rats
}

\author{
Mongi Saoudi ${ }^{1,2 \star}$, Mahfoud Messarah ${ }^{3}$, Amel Boumendjel $^{3}$, Abdelwaheb Abdelmouleh $^{2}$, \\ Wassim Kammoun ${ }^{2}$, Kamel Jamoussi ${ }^{4}$ and Abdelfattah El Feki ${ }^{1}$ \\ ${ }^{1}$ Animal Ecophysiology Laboratory, Sciences Faculty of Sfax, Tunisia. \\ ${ }^{2}$ Marine Biotechnology and Biodiversity Laboratory, INSTM of Sfax, Tunisia. \\ ${ }^{3}$ Animal Ecophysiology Laboratory, Sciences Faculty of Badji Mokhtar University, BP 12 Sidi Amar, Annaba, Algeria. \\ ${ }^{4}$ Biochemistry Laboratory, CHU Habib Bourguiba of Sfax, Tunisia.
}

Accepted 29 April, 2011

\begin{abstract}
This study aimed to investigate the toxicity of raw and boiled tissue extracts of Lagocephalus lagocephalus flesh or liver. Five groups of six male Wistar rats each were used. Four groups received a daily intraperitoneal injection of raw or boiled tissue extracts of $L$. lagocephalus flesh and liver at a dose of $1 \mathrm{ml} / 100 \mathrm{~g}(\mathrm{v} / \mathrm{w})$. The fifth group served as a sham and received a daily intraperitoneal injection of saline solution $(1 \mathrm{ml} / 100 \mathrm{~g}$ of $0.9 \% \mathrm{NaCl}, \mathrm{v} / \mathrm{w})$. During the experiment, there was a slight decrease in body weight in all treated groups. Our results revealed that the activities of various enzymes like transaminase, alkaline phosphatase (ALP), gamma glutamyl transpeptidase ( $\mathrm{Y}-\mathrm{GT}$ ) and lactate dehydrogenase (LDH) decreased in serum and increased in liver and kidney tissues, producing hepatotoxicity and nephrotoxicity in the treated rats. These observations on the toxicity of this Tunisian puffer fish revealing toxicity especially in the flesh, the edible part of fish, clearly indicate the danger of using this fish as food.
\end{abstract}

Key words: Hepatotoxicity, Lagocephalus lagocephalus, nephrotoxicity.

\section{INTRODUCTION}

Puffer fish poisoning is a form of ichthyosarcotoxism caused by the consumption of fish usually contaminated with toxic levels of the voltage-sensitive sodium channel activators named tetrodotoxin (TTX) (Lee et al., 2000). The distribution of TTX in puffer fish bodies appears to be species-specific. Furthermore, there is a compartment variability of TTX bioaccumulation, as shown by organs consumption toxicities. So, in marine species of puffer fish, liver and ovary generally present the highest toxicity, followed by intestines and skin. Thus, muscles in many toxic species are regarded as edible by the Japanese Ministry of Health and Welfare (Mahmud et al., 2001). The ingestion of these puffers has occasionally caused food poisoning including fatal cases (Kodama and Sato,

\footnotetext{
${ }^{\star}$ Corresponding author. E-mail: saoudimm@yahoo.fr Tel: 00216
} 74276 400. Fax: 0021674274437.
2005; Mahmud et al., 2000).

Yet, some of these species found along the Mexican coastline have been considered edible and non-toxic. Special regulations, for their consumption or preparation as food, are therefore required (Nuňez-Vaàzqueza et al., 2000). That is why several experimental studies demonstrating their adverse effects have been reported (Ahasan et al., 2004).

Because of the rapid poisoning, the irreversible and severe physiological damage caused by puffer fish intoxication, therapy is likely to have little or no value and effective prophylaxis is critical. In spite of the potential human hazards associated with puffer fish intoxication, very little work has been done on the development of effective antidotes for these cases of intoxication.

In our previous research, the Artemisia campestris extract (AE) was found to contain a large amount of polyphenols, some essential minerals $(\mathrm{Ca}, \mathrm{Mg}$ and $\mathrm{Zn}$ ) and exhibited two potent antioxidant abilities: DPPH 
model system and anion superoxide scavenging. Pretreatment for 10 days with $A$. campestris extract orally in rats at a dose $5 \mathrm{~g} / \mathrm{ml}$ protected against toxicity induced by the liver extract of pufferfish Lagocephalus lagocephalus (Saoudi et al., 2010).

Since the puffer fish is of considerable interest for food in many countries (Isbister et al., 2002), it is important to wonder about the origin of TTX in the food chain. Because of the ecological environments of TTX-bearing animals, it seems that they have no common factor other than being closely implicated in an aquatic system. Bacteria, the omnipresent organisms that commonly inhabit aquatic systems, are considered as the primary source of TTX. Thus, it is assumed that TTX- bearing puffer fish accumulate TTX in their body via the food chain. The production of TTX in microbes such as Vibrio sp. from the xanthid crab Amphicteis floridus (Wang and Fan, 2010), Schwanella alga and Alteromonas tetraodonis from the red calcareous alga Jania sp. (Lee et al., 2007) and strains of Vibrionaceae (Noguchi et al., 2006) infers that TTX originates from marine bacteria and accumulates in TTX-bearing animals when ingesting toxic organisms as food (Tsai et al., 2006). This postulation suggests that all TTX-bearing organisms are infected by TTX-producing microorganisms living symbiotically within their bodies, which is later confirmed by the isolation of TTX-producing bacteria from various TTX bearinganimals (Lee et al., 2007). Few reports mention that TTX may be synthesized in pufferfish themselves because in vivo cultured TTX-producing bacteria do not produce TTX in sufficient quantities, which explains the intoxication of TTX-bearing animals (Wu et al., 2005).

Human food poisoning through consumption of toxic puffers occurs especially in Japan and China where this fish flesh is considered a delicacy (Ahasan et al., 2004). The human distinctive form of ichthyosarcotoxism resulting from the consumption of contaminated species of fish is mainly characterized by gastro-intestinal, neurological and cardiovascular disorders (Lewis et al., 2000). Over the last decade, puffer fish L. lagocephalus have often been collected on the Tunisian coast.

These specimens were delivered fresh to our laboratory and the tissue extracts of different organs of puffer fish $L$. lagocephalus were tested to assess their safety on experimental animals. In our previous study (Saoudi et al., 2007), the toxicity risk of L. lagocephalus showed a disturbance in physiological and biochemical parameters in Wistar rats nourished with $L$. lagocephalus when compared with rats fed the diet contained a non toxic fish, the mule Liza aurata. The diet containing meat cooked with $L$. lagocephalus cooking water induced hepatotoxicity and oxidative stress in rats after $48 \mathrm{~h}$ and 2 months of treatment (Saoudi et al., 2009).

In this study, toxicity evaluation of flesh and liver of this fish was investigated in Wistar rats. Rats were daily injected for 10 days, with raw or boiled extracts of flesh or liver of $L$. lagocephalus. These extracts were prepared with or without heat treatment in order to determine their effects on some physiological and metabolic parameters in Wistar rats. To evaluate the toxicity of the treatment, the body and relative organ weights of liver, kidney, heart and spleen of the treated rats were determined. The activities of various enzymes like transaminane, alkaline phosphatase (ALP), gamma glutamyl transpeptidase ( $\mathrm{Y}$ GT) and lactate dehydrogenase (LDH) were recorded in serum, in liver and kidney of control and treated rats.

\section{MATERIALS AND METHODS}

\section{Sampling}

Specimens of puffer fish $(\mathrm{n}=10)$ L. lagocephalus (Linnaeus, 1766) were caught at different localities on the Tunisian coast and in the golf of Gabes, south of Tunisia, between 2003 and 2006 (May, June, July and August). Immediately following the collection, the fresh fish were eviscerated and frozen at $-20^{\circ} \mathrm{C}$ until used.

\section{Test for toxicity}

Briefly, one gram from each organ (flesh (including muscles and skin) and liver) was homogenized with $4 \mathrm{ml}$ of $0.1 \%$ acetic acid and centrifuged off. The obtained supernatant from specimens was toughened and its cumulus was aliquoted. Some aliquots of flesh and liver extracts were raw materials which were not boiled. Other extracts were boiled in a water bath for $10 \mathrm{~min}$ and cooled. These extracts were boiled materials. Each aliquot was conserved at $20^{\circ} \mathrm{C}$ until further use.

The protein content of flesh extract according to the method of Lowry et al. (1951) was $34.83 \pm 4.21$ and $21.4 \pm 1.54 \mathrm{mg} / \mathrm{ml}$ for raw and boiling extracts, respectively. The protein content of liver $L$. lagocephalus was $42.9 \pm 8.49$ and $32.66 \pm 2.8 \mathrm{mg} / \mathrm{ml}$ for raw and boiled extracts, respectively. The $\mathrm{pH}$ level was 7 in all extracts. On the day of the experiment, $1 \mathrm{ml}$ of the obtained supernatant was injected intraperitoneally into male mature Wistar rats for physiological evaluation ( $1 \mathrm{ml} / 100 \mathrm{~g}, \mathrm{v} / \mathrm{w}$ ) (El-Sayed et al., 2003).

\section{Rats farming}

Male Wistar rats $(n=30)$ weighing 148 to $151 \mathrm{~g}$ were purchased from the Central Pharmacy of Tunisia (SIPHAT, Tunisia). They were housed at $22^{\circ} \pm 3^{\circ} \mathrm{C}$ with light-dark periods of $12 \mathrm{~h}$ and minimum relative humidity of $40 \%$. All animals were fed a commercial balanced diet (SICO, Sfax, Tunisia) and had free access to water ad libitum. All animal experiments were conducted according to the Ethical Committee Guidelines for the care and use of laboratory animals of our institution.

\section{Experimental protocols}

After acclimatization to laboratory conditions for 1 week, animals were divided into five groups of six animals each: the first group served as control $(\mathrm{C})$ and received a daily intraperitoneal injection of vehicle $(1 \mathrm{ml}$ saline $+4 \mathrm{ml}$ of $0.1 \%$ acetic acid, boiled and cooled thereafter) at a dose of $1 \mathrm{ml} / 100 \mathrm{~g}$ of body weight. The second and the third groups were daily injected with $1 \mathrm{ml} / 100 \mathrm{~g}(\mathrm{v} / \mathrm{w})$ of raw or boiled flesh extract of $L$. lagocephalus (REf and BEf, respectively) and the fourth and the fifth groups were given the same dose of raw and boiled liver extract of $L$. lagocephalus (RE and $B E I$ respectively). 
Table 1. Body weight of controls and tissue extract of $L$. lagocephalus-exposed rats treated for 10 days by i.p. administration of extracts of flesh and liver L. lagocephalus $(1 \mathrm{ml} / 100 \mathrm{~g}, \mathrm{v} / \mathrm{w})$.

\begin{tabular}{lcccc}
\hline Control $(\mathbf{n}=\mathbf{6})$ & REf $(\mathbf{n}=\mathbf{6})$ & BEf $(\mathbf{n}=\mathbf{6})$ & REI $(\mathbf{n}=\mathbf{6})$ & BEI $(\mathbf{n}=\mathbf{6})$ \\
\hline Body weight $(\mathrm{g}):$ & & & & \\
Initial weight $(\mathrm{g}): 151 \pm 3.54$ & $150.6 \pm 5.66$ & $148.8 \pm 6.53$ & $149.8 \pm 5.33$ & $148.4 \pm 7.22$ \\
Final weight $(\mathrm{g}): 178.5 \pm 5.41$ & $159.25 \pm 7.99$ & $160.5 \pm 2.21$ & $158.75 \pm 7.96$ * & $156.75 \pm 6.02^{*}$ \\
\hline
\end{tabular}

Values are mean \pm SEM of six animals. ${ }^{*} p<0.05$ significant to control.

C, Control group received a daily intraperitoneal injection of vehicle $(1 \mathrm{ml} \mathrm{saline}+4 \mathrm{ml}$ of $0.1 \%$ acetic acid, boiled and cooled thereafter $)$ at a dose of $1 \mathrm{ml} / 100 \mathrm{~g}$ of body weight; REf and BEf, were daily injected with $1 \mathrm{ml} / 100 \mathrm{~g}(\mathrm{v} / \mathrm{w})$ of raw or boiled flesh extract of $L$. lagocephalus, respectively; REI and BEI, were given the same dose of raw and boiled liver extract of $L$. lagocephalus, respectively.

Table 2. Relative organ weights of controls and exposed rats treated for 10 days by i.p. administration of tissue extracts of flesh and liver L. lagocephalus (1 $\mathrm{ml} / 100 \mathrm{~g}, \mathrm{v} / \mathrm{w})$.

\begin{tabular}{ccccc}
\hline \multirow{2}{*}{ Treatment } & \multicolumn{3}{c}{ Relative organ weight $\mathbf{( g / 1 0 0 ~} \mathbf{g}$ body weight) } \\
\cline { 2 - 5 } & Liver & Kidney & Heart & Spleen \\
\hline C & $4.84 \pm 0.12$ & $0.38 \pm 0.01$ & $0.36 \pm 0.01$ & $0.35 \pm 0.03$ \\
REf & $4.47 \pm 0.13$ & $0.39 \pm 0.01$ & $0.35 \pm 0.01$ & $0.33 \pm 0.02$ \\
BEf & $4.90 \pm 0.13$ & $0.41 \pm 0.02$ & $0.35 \pm 0.005$ & $0.36 \pm 0.02$ \\
REI & $4.64 \pm 0.21$ & $0.41 \pm 0.01$ & $0.35 \pm 0.01$ & $0.32 \pm 0.02$ \\
BEl & $4.91 \pm 0.24$ & $0.41 \pm 0.01$ & $0.37 \pm 0.01$ & $0.31 \pm 0.02$ \\
\hline
\end{tabular}

Values are mean \pm SEM of six animals. No significant difference between control and treated groups $(P>0.05)$.

C, Control group received a daily intraperitoneal injection of vehicle ( $1 \mathrm{ml}$ saline $+4 \mathrm{ml}$ of $0.1 \%$ acetic acid, boiled and cooled thereafter) at a dose of $1 \mathrm{ml} / 100 \mathrm{~g}$ of body weight; REf and BEf, were daily injected with $1 \mathrm{ml} / 100 \mathrm{~g} \mathrm{(v/w)}$ of raw or boiled flesh extract of $L$. lagocephalus, respectively; $\mathbf{R E I}$ and $\mathbf{B E I}$, were given the same dose of raw and boiled liver extract of $L$. lagocephalus, respectively.

All experiments were initiated at the same hour $(8 \mathrm{am})$ to prevent biological rhythm changes. Body weights as well as food consumption were measured once a day.

\section{Collection and preparation of tissue}

At the end of the treatment (10 days), rats were sacrificed under anaesthesia with chloral hydrate intra-abdominally. For biochemical assays, blood was collected by heart puncture. Serum samples were obtained by centrifugation at $4000 \mathrm{rpm}$ for $15 \mathrm{~min}\left(4^{\circ} \mathrm{C}\right)$ and kept at $-30^{\circ} \mathrm{C}$ until analysis.

The liver, kidney, heart and spleen were removed, weighed, rinsed with ice-cold saline and kept at $-30^{\circ} \mathrm{C}$ until analysis. Various clinical variables related to hepatotoxicity and nephrotoxicity were studied. The frozen liver and kidney tissue samples were homogenized (Ultra Turrax T25, Germany) $(1: 2, \mathrm{w} / \mathrm{v})$ in $50 \mathrm{mmol} \mathrm{I}^{-1}$ phosphate buffer ( $\mathrm{pH} 7.4)$.

\section{Biochemical parameters analysis}

The liver and kidney homogenates and serum were taken to determine the following biochemical parameters: aspartate aminotransferase (AST), alanine aminotransferase (ALT), alkaline phosphatase (ALP), $\gamma$-Glutamyl transpeptidase ( $\gamma$-GT) and lactate dehydrogenase (LDH). The activities of ALT and AST were determined using commercial kits (Biotrol ALT/TGP, ref 03020; AST/TGO, ref 03010). Values of ALT and AST were derived based on the "absorptivity micromolar extinction coefficient" of NADH at $340 \mathrm{~nm}$. ALT and AST activities are expressed in terms of units per liter $(\mathrm{U} / \mathrm{L})$ are the amount of enzyme oxidizing one $\mu \mathrm{mol} / \mathrm{l}$ of $\mathrm{NADH}$ per minute.
The alkaline phosphatase (ALP) hydrolyzes the nitro-4phenylphosphate in the presence of 2-amino-1-propanol which is a transphophorylant agent. The catalytic activity of PAL was determined by measuring the rate of appearance of the nitro- 4 phenol, a product of the reaction and absorbance was measured at $405 \mathrm{~nm}$ using an ALP activity assay kit (Biotrol ALP SFBC 4x50 ml,

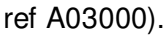

The $\mathrm{Y}$-Glutamyl transpeptidase $\left(\mathrm{\gamma}\right.$-GT) catalyzes the transfer of $\mathrm{Y}^{-}$ Glutamyl groups from L- Y - glutamylglycylglycine to glycylglycine, releasing the product p-nitroaniline that absorbs strongly at $405 \mathrm{~nm}$ using assay kit (biomaghreb, ref 20022).

LDH activity was determined photometrically, by using pyruvate as a supstrate (biomaghreb, ref 20012). These enzymes activities (AST, ALT, ALP, y-GT, LDH) were determined according to the protocols detailed in kits using a spectrophotometer.

\section{Statistical analysis}

The statistical analysis of the data was made using Student's $t$ - test. All values are expressed as means \pm SEM. Differences are considered significant if $p<0.05$.

\section{RESULTS}

The changes of body weights revealed that flesh extracts did not affect rat body weight gain in comparison to control. Contrarily, when using liver extracts, the body weight gain was significantly lower than shams (Table 1). However, as shown in Table 2, there were no significant differences in the overall average of relative organ 
Table 3. Diet intake in rats treated for ten days by i.p. administration of tissue extracts of flesh and liver L. lagocephalus $(1 \mathrm{ml} / 100 \mathrm{~g}, \mathrm{v} / \mathrm{w})$.

\begin{tabular}{cc}
\hline Treatment & Diet consumption (g/rat/day) \\
\hline C & $15.31 \pm 0.30$ \\
REf & $12.36 \pm 0.48^{* *}$ \\
BEf & $11.83 \pm 0.36^{* *}$ \\
REl & $12.12 \pm 0.38^{* *}$ \\
BEl & $11.92 \pm 0.44^{* *}$ \\
\hline
\end{tabular}

Values are mean \pm SEM of six animals. ${ }^{* *} p<0.01$ significant from control. C, Control group received a daily intraperitoneal injection of vehicle $(1 \mathrm{ml}$ saline $+4 \mathrm{ml}$ of $0.1 \%$ acetic acid, boiled and cooled thereafter) at a dose of $1 \mathrm{ml} / 100 \mathrm{~g}$ of body weight; REf and BEf, were daily injected with $1 \mathrm{ml} / 100 \mathrm{~g}(\mathrm{v} / \mathrm{w})$ of raw or boiled flesh extract of $L$. lagocephalus, respectively; REI and BEI, were given the same dose of raw and boiled liver extract of $L$. lagocephalus, respectively.

Table 4. Transaminase activity (AST and ALT) in serum, liver and kidney after treatment by i.p. administration of tissue extracts of flesh and liver L. lagocephalus $(1 \mathrm{ml} / 100 \mathrm{~g}, \mathrm{v} / \mathrm{w})$.

\begin{tabular}{|c|c|c|c|c|c|c|}
\hline \multirow{2}{*}{ Treatment } & \multicolumn{3}{|c|}{ AST activity (U/I) } & \multicolumn{3}{|c|}{ ALT activity (U/I) } \\
\hline & Serum & Liver & Kidney & Serum & Liver & Kidney \\
\hline C & $83.12 \pm 8.37$ & $16.18 \pm 1.94$ & $55.44 \pm 1.91$ & $12.95 \pm 0.89$ & $32.2 \pm 2.33$ & $21.35 \pm 3.72$ \\
\hline REf & $48.12 \pm 8.37\left(^{*}\right)$ & $24.15 \pm 3.19\left(^{*}\right)$ & $63.23 \pm 2.99\left(^{*}\right)$ & $8.75 \pm 0.95\left(^{*}\right)$ & $42.92 \pm 3.73\left(^{*}\right)$ & $54.25 \pm 12.99\left(^{*}\right)$ \\
\hline BEf & $49 \pm 10.2\left(^{*}\right)$ & $45.93 \pm 10.46\left(^{\star}\right)$ & $71.98 \pm 8.11\left(^{*}\right)$ & $\left.6.12 \pm 1.13^{(* *}\right)$ & $55.47 \pm 6.98\left(^{*}\right)$ & $51.18 \pm 14.18\left(^{*}\right)$ \\
\hline REI & $43.75 \pm 11.29\left(^{*}\right)$ & $24.5 \pm 1.01\left(^{*}\right)$ & $67.84 \pm 5.53\left(^{*}\right)$ & $7.43 \pm 1.65\left(^{*}\right)$ & $48.03 \pm 2.75\left(^{(* *}\right)$ & $38.5 \pm 4.28\left(^{*}\right)$ \\
\hline $\mathrm{BEI}$ & $\left.31.5 \pm 10.2^{* *}\right)$ & $31.93 \pm 6.71\left(^{*}\right)$ & $\left.82.53 \pm 2.49^{* *}\right)$ & $7.7 \pm 1.96\left(^{* \star}\right)$ & $\left.55.16 \pm 2.67^{* \star}\right)$ & $56.87 \pm 13.86\left(^{*}\right)$ \\
\hline
\end{tabular}

Values are expressed as mean $\pm \operatorname{SEM}(n=6) .{ }^{*} p<0.05$ and ${ }^{* *} p<0.01$ in relation to controls.

C, Control group received a daily intraperitoneal injection of vehicle ( $1 \mathrm{ml}$ saline $+4 \mathrm{ml}$ of $0.1 \%$ acetic acid, boiled and cooled thereafter) at a dose of 1 $\mathrm{ml} / 100 \mathrm{~g}$ of body weight; REf and BEf, were daily injected with $1 \mathrm{ml} / 100 \mathrm{~g}(\mathrm{v} / \mathrm{w})$ of raw or boiled flesh extract of $L$. lagocephalus, respectively; REI and BEI, were given the same dose of raw and boiled liver extract of $L$. lagocephalus, respectively.

weights (liver, kidney, heart and spleen) between the control and treated groups. The diet intake decreased $(p$ $<0.01$ ) during all treatment between the control and treated groups (Table 3 ). In our previous study, we examined some toxicity aspects of such organs orally administered in combination with diet. Hence, there were great differences between the animals' diet intake and subsequently, the administered dose.

The amount of TTX in the flesh and liver of puffer fish $L$. laocephalus was determined by the mouse bioassay toxicity method (Japan Food Hygiene Association, 2005). Weight, quantity injected and time to death or weight after $30 \mathrm{~min}$ were recorded and analyzed. Toxin concentration is expressed in $\mathrm{MU} / \mathrm{g}$ fish flesh or liver where $1 \mathrm{MU} / \mathrm{g}$ is 1 $\mathrm{g}$ of mouse killed $/ \mathrm{g}$ of fish flesh or liver. One mouse unit is equivalent to $0.22 \mu \mathrm{g}$ of TTX. The acute administration of flesh or liver extracts of $L$. lagocephalus provoked a decrease in transaminase (AST and ALT) activity (Table 4 ) in serum in all treated groups (REf, BEf, REI and BEI) compared with control group. However, the transaminase contents increased in liver and kidney in treated groups. In parallel with the effects of flesh and liver extracts of $L$. lagocephalus on transaminase activity, the ALP activity decreased also in serum and increased in liver and kidney after acute treatment in all experimental groups compared to the control group. Increases of LDH and $y$ GT activities in liver and kidney (Table 5) were found in all treated groups. Concomitantly, LDH and Y-GT activities in serum decreased in the treated groups when compared with controls.

\section{DISCUSSION}

Information on the safety of puffer fish L. lagocephalus consumption is scarce. This experimental animal model procedure may constitute a preliminary investigation regarding human poisoning. In a previous study, $L$. Lagocephalus organ extracts were shown to be toxic, but at various degrees. Such results may come from an unequal TTX biodistributon in the bearing fish body compartments. The results of the relative toxicity of flesh and liver $(\mathrm{MU} / \mathrm{g})$ of $L$. lagocephalus by relation dosedeath time (mouse unit relation for TTX) were published in previous study (Saoudi et al., 2008). L. Lagocephalus liver extract was explored to demonstrate the most potent toxicity of this organ (Saoudi et al., 2008).

The obtained results herein mitigate those reported by 


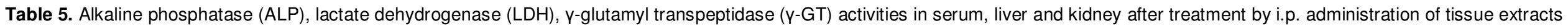
of flesh and liver $L$. lagocephalus $(1 \mathrm{ml} / 100 \mathrm{~g}, \mathrm{v} / \mathrm{w})$.

\begin{tabular}{|c|c|c|c|c|c|c|c|c|c|}
\hline \multirow{2}{*}{ Treatment } & \multicolumn{3}{|c|}{ ALP activity (U/I) } & \multicolumn{3}{|c|}{ LDH activity (U/I) } & \multicolumn{3}{|c|}{ y GT activity (U/I) } \\
\hline & Serum & Liver & Kidney & Serum & Liver & Kidney & Serum & Liver & Kidney \\
\hline C & $586.43 \pm 47.09$ & $31.62 \pm 7.31$ & $42.35 \pm 2.97$ & $701.56 \pm 71.39$ & $817.59 \pm 13.05$ & $999.73 \pm 133.08$ & $4.65 \pm 0.73$ & $3.85 \pm 1.24$ & $13.11 \pm 0.88$ \\
\hline REf & $\begin{array}{c}418 \pm 45.81 \\
\left({ }^{*}\right)\end{array}$ & $\begin{array}{c}96.25 \pm 20.23 \\
\left(^{*}\right)\end{array}$ & $\begin{array}{c}60.77 \pm 6.59 \\
\left({ }^{*}\right)\end{array}$ & $\begin{array}{c}463.16 \pm 23.88 \\
\left(^{*}\right)\end{array}$ & $\begin{array}{c}934.16 \pm 43.48 \\
\left({ }^{*}\right)\end{array}$ & $\begin{array}{c}1453.65 \pm 113.2 \\
\left({ }^{*}\right)\end{array}$ & $\begin{array}{c}2.14 \pm 0.73 \\
\left(^{*}\right)\end{array}$ & $\begin{array}{c}8.17 \pm 0.94 \\
\left(^{*}\right)\end{array}$ & $\begin{array}{c}23.22 \pm 4.45 \\
\left(^{*}\right)\end{array}$ \\
\hline BEf & $\begin{array}{c}431.06 \pm 41.54 \\
\left({ }^{*}\right)\end{array}$ & $\begin{array}{c}82.5 \pm 15.87 \\
\left(^{*}\right)\end{array}$ & $\begin{array}{c}53.9 \pm 3.95 \\
\left(^{*}\right)\end{array}$ & $\begin{array}{c}403.63 \pm 84.63 \\
\left({ }^{*}\right)\end{array}$ & $\begin{array}{c}1279.01 \pm 201.69 \\
\left({ }^{*}\right)\end{array}$ & $\begin{array}{c}1548.89 \pm 202.29 \\
\left(^{*}\right)\end{array}$ & $\begin{array}{c}2.25 \pm 0.54 \\
\left(^{*}\right)\end{array}$ & $\begin{array}{c}12.3 \pm 2.58 \\
\left(^{*}\right)\end{array}$ & $\begin{array}{c}27.19 \pm 5.39 \\
\left(^{*}\right)\end{array}$ \\
\hline REl & $\begin{array}{c}413 \pm 48.88 \\
\left(^{*}\right)\end{array}$ & $\begin{array}{c}88.91 \pm 17.12 \\
\left(^{*}\right)\end{array}$ & $\begin{array}{c}52.73 \pm 3.57 \\
\left({ }^{*}\right)\end{array}$ & $\begin{array}{c}446.58 \pm 67.15 \\
\left({ }^{*}\right)\end{array}$ & $\begin{array}{c}1385.86 \pm 181.16 \\
\left({ }^{*}\right)\end{array}$ & $\begin{array}{c}1529.95 \pm 117.47 \\
\left(^{*}\right)\end{array}$ & $\begin{array}{c}2.24 \pm 0.56 \\
\left(^{*}\right)\end{array}$ & $\begin{array}{c}9.25 \pm 1.36 \\
\left(^{*}\right)\end{array}$ & $\begin{array}{c}31.73 \pm 6.28 \\
\left(^{*}\right)\end{array}$ \\
\hline $\mathrm{BEI}$ & $\begin{array}{c}438.16 \pm 9.94 \\
\left({ }^{*}\right)\end{array}$ & $\begin{array}{c}97.62 \pm 25.63 \\
\left(^{*}\right)\end{array}$ & $\begin{array}{c}61.05 \pm 6.98 \\
\left({ }^{*}\right)\end{array}$ & $\begin{array}{c}377.13 \pm 90.14 \\
\left({ }^{*}\right)\end{array}$ & $\begin{array}{c}1308.15 \pm 198.69 \\
\left(^{*}\right)\end{array}$ & $\begin{array}{c}1363.89 \pm 57.45 \\
\left(^{*}\right)\end{array}$ & $\begin{array}{c}2.61 \pm 0.28 \\
\left({ }^{\star}\right)\end{array}$ & $\begin{array}{c}8.41 \pm 1.45 \\
\left(^{*}\right)\end{array}$ & $\begin{array}{c}28.05 \pm 4.91 \\
\left(^{*}\right)\end{array}$ \\
\hline
\end{tabular}

Values are expressed as mean $\pm \operatorname{SEM}(n=6) .{ }^{*} \mathrm{p}<0.05$ and ${ }^{* *} \mathrm{p}<0.01$ in relation to controls.

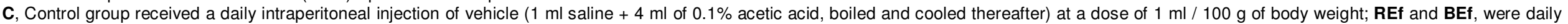

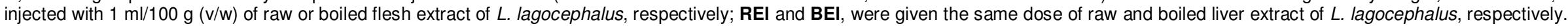

Hwang and Noguchi (2007) and Ghosh et al. (2004), who studied different organs of other puffer fish and showed that puffer toxins were concentrated in ovaries and liver, with lesser amounts present in the digestive tract and flesh. In contrast, our results indicate that flesh, the edible part of fish contained $10.28 \mathrm{MU} / \mathrm{g}$ of TTX (Saoudi et al., 2008). Previous data of El-Sayed et al. (2003) indicated that $3000 \mathrm{MU}$ can be fatal to humans. So, about $300 \mathrm{~g}$ of flesh of $L$. lagocephalus is enough to kill a human. This reflects the danger of using this part of fish as a food.

In experimental animal exposure, it has been shown that adult male Wistar rats treated with flesh and liver extracts of $L$. lagocephalus showed a slight decrease in body weight. The reduction in body weight is mainly attributed to the reduction in food intake of the treated rats compared with control. This result is in agreement with several studies observed in mice exposed to okadaic acid (a marine toxin) which induced a reduction in body weight after 5 days of treatment (Tubaro et al., 2003). During the experimental period, a decrease in food consumption associated with diarrhea was the cause of growth-rate reduction of adult treated rats.

The toxin of $L$. lagocephalus (TTX) is known to have diverse effects on the organism cells. In this study, we investigated the hepato and nephrotoxic effect of flesh and liver extracts of $L$. lagocephalus on rats. We observed that boiled or raw extracts of $L$. lagocephalus induced an elevated level of transaminase (AST and ALT), ALP, LDH and $y$ GT in liver and a decrease of these enzymes in serum. This biochemical disorder was marked in different treated groups (REf, BEf, REl and BEI), when compared with their corresponding control groups. Also, the biochemical changes in the liver profile could be related to hepatocyte damage. Furthermore, these changes appeared not to be altered by heat treatment. Hence, the cytotoxic factor of $L$. lagocephalus seemed to be heatstable as demonstrated in previous study (Saoudi et al., 2007). The overall changes in LDH activity in flesh and liver extracts of $L$. lagocephalus treated rats may be due to severe cellular damage leading to the release of enzymes and impairing carbohydrate and protein metabolism. Kumar et al. (2002) reported serious effects of ricin (a potent plant toxin) on liver functions, using ALP, $\mathrm{LDH}$, serum AST and serum ALT as markers for liver functions. The activity of these enzymes was altered in the blood and liver function. Renal 
failure has been reported with flesh and liver extracts of L. lagocephalus intoxication. A significant increase in the kidney tissue and decrease in plasma of transaminase (AST and ALT), ALP, LDH and Y-GT activities was indicative of kidney damage. This result is in agreement with several studies (Nobre et al., 2003), which suggested that cyanotoxins promoted renal alterations and affected renal physiology. On the other hand, the enhancement of enzymes activities in the renal tissue of the treated groups is involved in protective mechanisms that modulate cellular responses to toxic compounds. All the parameters such as alanine aminotransferase (ALT), aspartate aminotransferase (AST), alkaline phosphatase (ALP), $\mathrm{Y}$-glutamyl transpeptidase ( $\mathrm{Y}$-GT) and lactate dehydrogenase (LDH) levels of serum decreased and increased significantly in liver and kidney tissues in experimental groups in comparison to those of control group, indicating that the tetrodotoxin (TTX) had toxic effects on liver and kidney functions.

Based on the experimental findings of our study, we demonstrated that raw or boiled tissue extracts of $L$. lagocephalus exhibited hepatotoxic and nephrotoxic effects in all treated groups compared with controls after treatment. Thus, the ingestion of raw or cooked organs of this Tunisian puffer fish, including its flesh, induced toxicity and clearly indicated the danger of using this fish as food.

\section{ACKNOWLEDGEMENTS}

The authors express their gratitude to $\operatorname{Pr}$ Michael $\mathrm{L}$. Dourson, Toxicology Excellence for Risk Assessment (TERA, USA) for her constructive revision of the manuscript. This work was supported by the project Tuniso-Algerian and the DGRST grants: 09/UR/06 in Tunisia.

\section{REFERENCES}

Ahasan H, Mamun AA, Karim SR, Bakar MA, Gazi EA, Bala CS (2004). Paralytic complications of pufferfish (Tetrodotoxin) poisoning. Singap. Med. J., 45: 73-75.

aqueous extract of Artemisia campestris on tissue extract from poisonous fish Lagocephalus lagocephalus-induced oxidative damage in rats. Exp. Toxicol. Pathol., 62: 601-605.

El-Sayed M, Yacout GA, El-Samra M, Ali A, Kotb SM (2003). Toxicity of the Red Sea pufferfish Pleuranacanthus sceleratus "El-Karad". Ecotox. Environ. Safe, 56: 367-372.

Ghosh S, Hazra AK, Banerjee S, Mukherjee B (2004). The seasonal toxicological profile of four puffer fish species collected along Bengal coast, India. Ind. J. Mar. Sci., 33: 276-280.

Hwang DF, Noguchi T (2007). Tetrodotoxin Poisoning. Adv. Food Nutr. Res., 52: 141-236.

Isbister GK, Son J, Wang F, Maclean CJ, Lin CSY, Ujma J, Balit CR, Smith B, Milder DG, Kiernan MC (2002). Puffer fish poisoning: a potentially life-threatening condition. Med. J. Aust., 177: 650-653.
Japan Food Hygiene Association (2005). Puffer toxin. In: Environmental Health Bureau, Ministry of Health and Welfare, ed. Shokuhin Eisei Kensa Shishin (Manual for Methods for Food Sanitation Testing), Tokyo, 661-673.

Kodama M, Sato S (2005). Pufferfish toxin. In: Bureau of Environmental Health. Ministry of Health and Welfare, Japan (Ed.), The Manual for the Methods of Food Sanitation Tests. Food Hyg. Assoc. Tokyo, 661-666.

Kumar O, Sugendran K, Vijayaraghavan R (2003). Oxidative stress associated hepatic and renal toxicity induced by ricin in mice. Toxicon., 41 : 333-338.

Lee $\mathrm{JH}$, Kondo H, Sato S, Akimoto S, Saito T, Kodama M, Watabe S (2007). Identification of novel genes related to tetrodotoxin intoxication in pufferfish. Toxicon., 49: 939-953.

Lee MJA, Jeong DY, Kim WS, Kim HD, Kim CH, Park WW (2000). A tetrodotoxin-producing Vibrio-strain, LM-1, from the puffer fish Fugu vermicularis radiatus. App. Env. Microbiol., 66: 1698-1701.

Lewis RJ, Molgo J, Adams DJ (2000). Ciguatera toxins: pharmacology of toxins involved in ciguatera and related fish poisoning, in: L.M. Botana (Ed.), Seafood and Freshwater Toxins Pharmacology, Physiology and Detection. M. Dekker Inc., New-York; p. 419-447.

Lowry OH, Rosebrough NJ, Farr AL, Randall RJ (1951). Protein measurement with Folin phenol reagent. J. Biol. Chem., 193: 265 275.

Mahmud Y, Arakawa O, Noguchi T (2000). An epidemic survey on freshwater puffer poisoning in Bangladesh. J. Nat. Toxins. 9: 319-26.

Mahmud Y, Tanu MB, Takatani T, Asayama E, Arakawa O, Noguchi T (2001). Chelonodon patoca, a highly toxic marine puffer in Japan. J. Nat. Toxins., 10: 69-74.

Nobre ACL, Martins AMC, Havt A, Benevides C, Lima AAM, Fonteles MC (2003). Renal effects of supernatant from rat peritoneal macrophages activated by microcystin-LR: role protein mediators. Toxicon., 41: 377-381.

Noguchi T, Arakawa O, Takatani T (2006). TTX accumulation in pufferfish. Comp. Biochem. Phys., 1: 145-152.

Nuňez-Vaàzqueza EJ, Yotsu-Yamashitab $M$, Sierra-Beltraňna AP, Yasumoto T, Ochoaa JL (2000). Toxicities and distribution of tetrodotoxin in the tissues of puffer fish found in the coast of the Baja California Peninsula, Mexico. Toxicon., 38: 729-34.

Saoudi M, Abdelmouleh A, Ellouze F, Jammoussi K, El Feki A (2009). Oxidative stress and hepatotoxicity in rats induced by poisonous pufferfish Lagocephalus lagocephalus meat. J. Venom. Anim. Toxins., 15: 424-443.

Saoudi M, Abdelmouleh A, Jamoussi K, Kammoun A, El Feki A (2008). Hematological toxicity associated with tissue extract from poisonous fish Lagocephalus lagocephalus-influence on erythrocyte function in wistar rats. J. Food Sci., 73: 155-159.

Saoudi M, Allagui MS, Abdelmouleh A, Jamoussi K, El Feki A (2010). Protective effect of poisoning in Bangladesh. J. Nat. Toxins., 9: 319326.

Saoudi M, Ben Rabeh F, Jammoussi K, Abdelmouleh A, Belbahri L, El Feki A (2007). Biochemical and physiological responses in wistar rat after administration of puffer fish (Lagocephalus lagocephalus) flesh. J. Food Agric. Environ., 2: 107-111.

Tsai YH, Ho PH, Hwang CC, Hwang PA, Cheng CA, Hwang DF (2006). Tetrodotoxin in several species of xanthid crabs in southern Taiwan. Food Chem., 95: 205-212.

Tubaro A, Sosa S, Carbonatto M, Altinier G, Vita F, Melato M (2003). Oral and intraperitoneal acute toxicity studies of yessotoxin and homoyessotoxin in mice. Toxicon., 41: 783-792.

Wang J, Fan Y (2010). Isolation and characterization of a Bacillus species capable of producing tetrodotoxin from the puffer fish Fugu obscurus. World J. Microbiol. Biotechnol., 10: 354-352.

Wu Z, Yang Y, Xie L, Xia G, Hu J, Wang S, Zhang R (2005). Toxicity and distribution of tetrodotoxin-producing bacteria in puffer fish Fugu rubripes collected from the Bohai Sea of China. Toxicon., $46: 471-476$ 